ISSN 1678-3921

Journal homepage: www.embrapa.br/pab

For manuscript submission and journal contents, access: www.scielo.br/pab

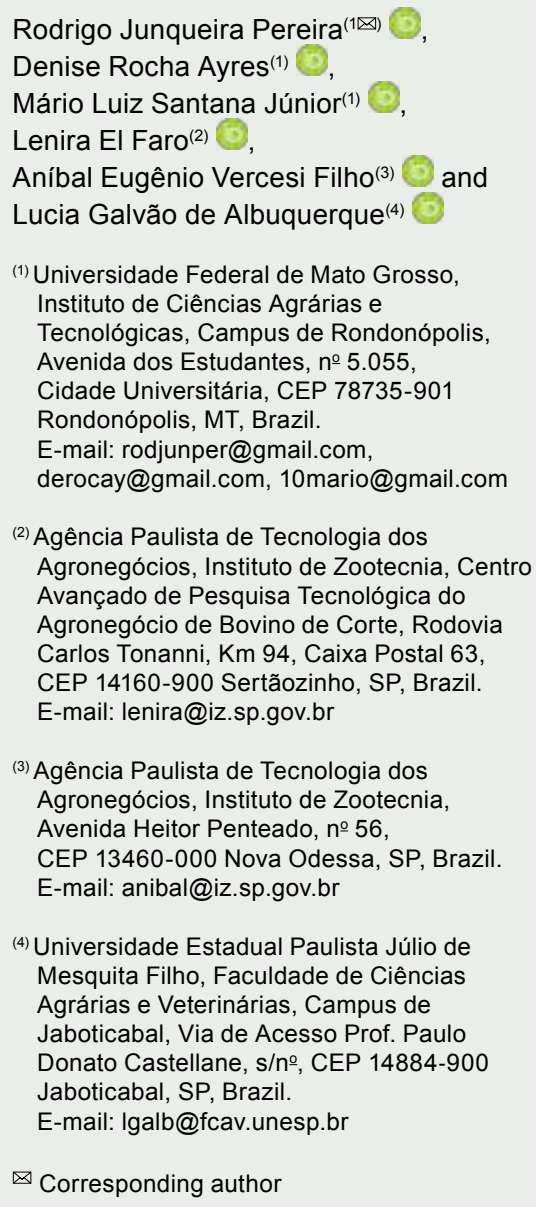

(3) Agência Paulista de Tecnologia dos Agronegócios, Instituto de Zootecnia, Avenida Heitor Penteado, no 56, CEP 13460-000 Nova Odessa, SP, Brazil. E-mail: anibal@iz.sp.gov.br

(4) Universidade Estadual Paulista Júlio de Mesquita Filho, Faculdade de Ciências Agrárias e Veterinárias, Campus de Jaboticabal, Via de Acesso Prof. Paulo Donato Castellane, s/no, CEP 14884-900 Jaboticabal, SP, Brazil.

E-mail: Igalb@fcav.unesp.br

$\bowtie$ Corresponding author

Received

May 10, 2018

Accepted

August 31, 2018

How to cite

PEREIRA, R.J.; AYRES, D.R.; SANTANA JR. M.L.; EL FARO, L.; VERCESI FILHO, A.E.; ALBUQUERQUE L.G. de. Test-day or 305-day milk yield for genetic evaluation of Gir cattle. Pesquisa Agropecuária Brasileira, v.54, e00325, 2019. DOI: https://doi.org/10.1590/ S1678-3921.pab2019.v54.00325.

\section{Test-day or 305-day milk yield for genetic evaluation of Gir cattle}

\begin{abstract}
The objective of this work was to compare genetic evaluations of milk yield in the Gir breed, in terms of breeding values and their accuracy, using a random regression model applied to test-day records or the traditional model (TM) applied to estimates of 305-day milk yield, as well as to predict genetic trends for parameters of interest. A total of 10,576 first lactations, corresponding to 81,135 test-day (TD) records, were used. Rank correlations between the breeding values (EBVs) predicted with the two models were 0.96 . The percentage of animals selected in common was 67 or $82 \%$, respectively, when 1 or $5 \%$ of bulls were chosen, according to EBVs from random regression model (RRM) or TM genetic evaluations. Average gains in accuracy of 2.7, 3.0 , and $2.6 \%$ were observed for all animals, cows with yield record, and bulls (sires of cows with yield record), respectively, when the RRM was used. The mean annual genetic gain for 305-day milk yield was $56 \mathrm{~kg}$ after 1993. However, lower increases in the average EBVs were observed for the second regression coefficient, related to persistency. The RRM applied to TD records is efficient for the genetic evaluation of milk yield in the Gir dairy breed.
\end{abstract}

Index terms: accuracy, persistency, random regression, rank correlation.

\section{Produção de leite diária ou acumulada até os 305 dias de lactação na avaliação genética de bovinos Gir}

Resumo - O objetivo deste trabalho foi comparar as avaliações genéticas da produção de leite na raça Gir, em termos dos valores genéticos preditos e de suas acurácias, por meio de modelo de regressão aleatória aplicado aos registros de produção de leite no dia do controle ou de modelo tradicional aplicado às estimativas de produção de leite acumulada em até 305 dias de lactação, bem como predizer tendências genéticas para parâmetros de interesse. Um total de 10.576 primeiras lactações, que correspondem a 81.135 registros de produção de leite no dia do controle (PLDC), foi utilizado. As correlações de ordem entre os valores genéticos preditos (VGP) com os dois modelos foram de 0,96 . O percentual de animais em comum foi de 67 ou $82 \%$, respectivamente, quando 1 ou $5 \%$ dos touros foram escolhidos, de acordo com os VGP das avaliações genéticas utilizando um ou outro modelo. Foram observados ganhos médios em acurácia de 2,7, 3,0 e 2,6\% para todos os animais, vacas com fenótipo e touros (pais de vacas com fenótipo), respectivamente, quando o modelo de regressão aleatória (MRA) foi utilizado. O ganho genético médio anual para a produção de leite acumulada em até 305 dias de lactação foi de $56 \mathrm{~kg}$ após 1993. Entretanto, menores incrementos na média dos VGP foram observados para o segundo coeficiente de regressão, relacionado à persistência. O MRA aplicado às PLDC é eficiente para as avaliações genéticas da produção de leite na raça Gir Leiteiro.

Termos para indexação: acurácia, persistência, regressão aleatória, correlação de ordem. 


\section{Introduction}

Random regression models have been used in different countries for genetic evaluations of productive traits in dairy cattle (Interbull, 2017). These models employ test-day milk yield records instead of estimates of 305-day cumulative milk yield (Y305) data. Their advantages, compared with the models using Y305, are the following: not requiring adjustment factors to extend partial lactations; allowing to consider specific factors for each test day, such as management groups within a herd; allowing to more adequately quantify environmental effects; solving the problem of differences in the amount of information that contributes to the estimation of Y305; and allowing the calculation of breeding values for milk yield persistency as a function of days in milk (Jamrozik et al., 2002). In addition, the use of random regression models is associated with an increase in the accuracy of genetic evaluations, as shown in studies using simulated (Kistemaker, 1997; Meyer, 2004) and real data (Boligon et al., 2011; Santos et al., 2014).

The Gir (Bos indicus) breed is found throughout Brazil, representing the second largest Zebu population in the country, with a total of 799,284 recorded animals until 2015 (ABCZ, 2017). The ability of this breed to be raised on pasture, as well as its resistance to endo- and ectoparasites and its adaptation to high temperatures, has raised the interest of other tropical countries, resulting in the exportation of semen and animals to Africa and Central and South America and, more recently, to India, where the Gir breed originated from (Pereira et al., 2013a).

Genetic evaluations of productive traits in dairy Gir cattle in Brazil have been conducted using an animal model for the estimates of Y305 from multiple lactations (Panetto et al., 2018). In this respect, studies have tried to develop an adequate random regression model that uses test-day milk yield records for the evaluation of the breed (Herrera et al., 2008; Pereira et al., 2010, 2012, 2013a, 2013b; Gonzalez-Herrera et al., 2015; Santana Jr. et al., 2015; Oliveira et al., 2017). However, none of these researches showed a potential increase in the accuracy of estimated breeding values (EBVs) when applying random regression models to test-day milk yield records.

The objective with this work was to compare genetic evaluations of milk yield in the Gir breed, in terms of breeding values and their accuracy, using a random regression model applied to test-day records or the traditional model applied to estimates of 305day milk yield, as well as to predict genetic trends for parameters of interest.

\section{Materials and Methods}

The used test-day milk yield (TDMY) records of first-lactation dairy Gir cows from herds located in different states of Brazil were provided by Associação Brasileira dos Criadores de Gir Leiteiro.

The criteria for the inclusion of cows in the study were: age at first calving ranging from 20 to 60 months; first test-day record obtained within 45 days after calving; interval between test-day records less than 45 days; a minimum of three test-day records during lactation; and only complete lactations. Cows with Y305 or lactation length outside the mean \pm 3.5 standard deviations were excluded from the study. Cows belonging to contemporary groups (CGs), i.e., herd-year-season of calving, with fewer than three animals were also eliminated. Connectedness among CGs was evaluated using the AMC software (Roso \& Schenkel, 2006), and those with fewer than ten direct genetic links were excluded. After the application of these constraints, the analyses included 10,576 first lactations, corresponding to 81,135 TDMY records. According to a previous study (Pereira et al., 2013a), based on the level of TDMY and the shape of the lactation curve, the cows were divided into eight subclasses of age-season of calving, considering two seasons (April-September and October-March) and four age classes $(20-35,36-47,48-56$, and 57-60 months). The TDMY records were divided into subclasses of herd-year of calving, including 12 classes of 2 years each (1988-1989, ..., 2012-2013). Table 1 shows the structure of the dataset after the application of the described constraints. The pedigree file contained 24,205 animals.

The analyses were performed under an animal model by the restricted maximum likelihood method using the Wombat software (Meyer, 2007). In the first analysis, the RRM, described as follows, was applied to TDMY records:

$$
\begin{aligned}
& \mathrm{TDMY}_{\mathrm{ijkloc}}=\mathrm{HYM}_{\mathrm{i}}+\mathrm{AS}_{\mathrm{jo}}+\mathrm{MF}_{\mathrm{ko}}+\sum_{\mathrm{m}=1}^{4} \beta_{\mathrm{lm}} \varphi_{\mathrm{m}}(\mathrm{d})+ \\
& \sum_{\mathrm{m}=1}^{4} \pm_{\mathrm{cm}} \varphi_{\mathrm{m}}(\mathrm{d})+\sum_{\mathrm{m}=1}^{4} \mathrm{p}_{\mathrm{cm}} \varphi_{\mathrm{m}}(\mathrm{d})+\mathrm{e}_{\mathrm{ijkloc}}
\end{aligned}
$$


where $\mathrm{TDMY}_{\mathrm{ijkloc}}$ is the test-day milk yield record; $\mathrm{HYM}_{\mathrm{i}}$ is the effect of the $\mathrm{i}^{\text {th }}$ subclass of herd-year-month of the test; $\mathrm{AS}_{\mathrm{jo}}$ is the fixed effect of the $\mathrm{j}^{\text {th }}$ subclass of age-season of calving nested within class o of days of lactation (20 classes of 15 days: 5-19, .., 289-305); $\mathrm{MF}_{\mathrm{ko}}$ is the fixed effect of the $\mathrm{k}^{\text {th }}$ class of milking frequency $(\mathrm{k}=1,2$, or 3 times a day) nested within class o of days of lactation (20 classes of 15 days: 5-19, $\ldots, 289-305) ; \beta_{\operatorname{lm}}$ is the $\mathrm{m}^{\text {th }}$ fixed regression coefficient specific for the $1^{\text {th }}$ subclass of herd-year of calving; $\alpha_{\mathrm{cm}}$ and $\mathrm{p}_{\mathrm{cm}}$ are the $\mathrm{m}^{\text {th }}$ regression coefficients for random additive genetic and permanent environmental effects of cow c, respectively; $\varphi_{\mathrm{m}}(\mathrm{d})$ is the $\mathrm{m}^{\text {th }}$ orthogonal Legendre polynomial corresponding to day $d$ of lactation; and $\mathrm{e}_{\mathrm{ijkloc}}$ is the residual effect associated with the record. Cubic orthogonal Legendre polynomials were used for fixed and random regressions according to Pereira et al. (2013b).

For the RRM, the same residual variance was assumed within the following intervals: 5-30, 31-60, 61-120, 121-270, and 271-305 days in milk according to the recommendation of Pereira et al. (2013b). In addition, the residuals for different days of lactation were considered not to be correlated.

At the end of the process of the estimation of covariance components, a genetic evaluation was performed using the final estimates of the covariance matrices as input. The EBVs for the random regression coefficients were used to estimate breeding values

Table 1. Characteristics of the dataset used in the analysis ${ }^{(1)}$.

\begin{tabular}{lccc}
\hline Characteristics & $\begin{array}{c}\text { TDMY } \\
\text { (kg per day) }\end{array}$ & $\begin{array}{c}\text { Y305 } \\
(\mathrm{kg})\end{array}$ & $\begin{array}{c}\text { LL } \\
\text { (days) }\end{array}$ \\
\hline Number of records & 81,135 & 10,576 & 10,576 \\
Number of cows with records & 10,576 & 10,576 & 10,576 \\
Mean number of records per herd & 92.1 & 12.0 & 12.0 \\
Mean number of records per CG ${ }^{(2)}$ & 10.1 & 12.0 & 12.0 \\
Mean number of records per HC & 126.4 & - & - \\
Mean of the trait & 13.21 & 3,614 & 297.4 \\
Standard deviation of the trait & 6.56 & 1,863 & 78.7 \\
Minimum & 0.10 & 262.0 & 90.0 \\
Maximum & 42.10 & 12,340 & 520.0 \\
\hline
\end{tabular}

${ }^{(1)} \mathrm{CG}$, contemporary group; $\mathrm{HC}$, herd-calving period, including 12 periods of 2 years each; TDMY, test-day milk yield; Y305, estimates of 305-day cumulative milk yield; and LL, lactation length. ${ }^{(2)}$ Herd-year-month of the test for TDMY, and herd-year-season of calving for Y305 and LL. for Y305, i.e., the sum of the daily EBV. In the second analysis, the traditional model (TM), fitted to estimates of Y305, was used for the genetic evaluation of the animals. The fixed effects of CGs and age of cow at calving (linear and quadratic effects), as well as random additive genetic and residual effects, were included in this model. Input values for additive genetic and residual variances were obtained using the final estimates of the covariance matrices from the random regression analysis. The Y305 additive genetic variance was the sum of the daily additive genetic variances from 5 to 305 days, and the Y305 residual variance was the sum of the daily permanent environment variances plus the sum of the daily residual variances.

The two studied models were compared in terms of rank correlation between EBVs for Y305 (EBV305) and the percentage of animals in common, i.e., animals selected by both models when different selection intensities were applied based on EBV305. It is important to note that rank correlation here does not point out the best model, but shows if ranking and selection using EBVs from the RRM are (or not) similar to those for the TM.

Moreover, the accuracy of EBV305 was calculated using the inverse of the coefficient matrix in the two analyses: $\sqrt{1-\mathrm{PEV} / \sigma_{\mathrm{a}}^{2}}$, where PEV is the variance of the prediction error and $\sigma_{\mathrm{a}}{ }^{2}$ is the additive genetic variance.

For the random regression analysis, the PEV of Y305 was calculated according to Meyer (2004); in this case, the "diagonal block" for each set of random regression coefficients provides an estimate of the covariances of the prediction error among the coefficients for an animal. The called "diagonal blocks" are formed from selected elements of the inverse of the coefficient matrix in the mixed model equations pertaining to sets of random regression coefficients for the genetic additive effect. Corresponding PEVs of breeding values for Y305, therefore, were obtained from the estimated covariances among random regression coefficients, as: $\mathrm{PEV}_{\mathrm{a}}=v^{\prime} \mathrm{M}_{\mathrm{a}} \mathrm{v}$, where $\mathrm{v}=[212.839,0.000,1.586$, $0.000]$ is the vector (linear function) that represents the sums of the Legendre covariables for each of the four regression coefficients in the interval from 5 to 305 days in milk; and $\mathrm{M}_{\mathrm{a}}$ is the matrix with "diagonal block" elements for a specific animal a. 
Considering the period from 1965 to 2009, the genetic trends for Y305 and for the first two regression coefficients of the orthogonal Legendre polynomials were estimated based on EBVs, using the RRM.

\section{Results and Discussion}

The heritabilities for the daily milk yields estimated with the RRM ranged from 0.15 to 0.21 , which are of similar magnitude to those reported for milk yield in dairy Gir cattle (Herrera et al., 2008; Pereira et al., 2010, 2013a, 2013b; Oliveira et al., 2017). The heritability for the first regression coefficient (intercept), corresponding to that for total lactation (305-day) milk yield (Jamrozik et al., 2002), was 0.27.

The mean, standard deviation, and range of the EBV305 obtained with the TM were higher than those estimated with the RRM (Table 2). Rank correlations between the EBV305 from the two models were 0.96 for all animals, cows with yield record, and bulls (sires of cows with known yield). These correlations indicate that the re-ranking of the animals can be expected when one or the other model is used for genetic evaluation. Lower correlations have been found by Herrera et al. (2008) for dairy Gir cattle and by Santos et al. (2014) for the Guzerá breed. These results are probably due to differences in data consistency requirements, in the functions used to fit random effects and in the fixed effects included in the RRM. However,

Table 2. Number of animals, mean, standard deviation (SD), and minimum and maximum estimated breeding values for cumulative 305-day milk yield ${ }^{(1)}$.

\begin{tabular}{lccccc}
\hline Model & Number & Mean & SD & Minimum & Maximum \\
\hline \multicolumn{5}{c}{ All animals } \\
RRM & 23,822 & 330.9 & 481.1 & -814.6 & $2,458.9$ \\
TM & 23,822 & 406.3 & 573.2 & $-1,080.9$ & $3,978.9$ \\
\hline & & \multicolumn{5}{c}{ Cows $^{(2)}$} \\
RRM & 10,576 & 616.7 & 515.9 & -814.6 & $2,458.9$ \\
TM & 10,576 & 748.0 & 613.9 & -947.4 & $3,078.9$ \\
\hline & & & Bulls $^{(3)}$ & & \\
RRM & 877 & 283.2 & 425.0 & -611.8 & $2,084.3$ \\
TM & 877 & 354.1 & 505.6 & -724.3 & $2,429.5$ \\
\hline
\end{tabular}

(1)RRM, random regression model using test-day milk yields; and TM, traditional model using estimates of 305-day cumulative milk yield. (2) Cows with known yield. ${ }^{(3)}$ Bulls with female offspring with known yield.
Schaeffer et al. (2000), while evaluating different dairy breeds in Canada, reported correlations similar to those found in the present study.

The percentage of animals in common was relatively low when 1 or $5 \%$ bulls were chosen to sire the next generation, according to EBVs from RRM or TM genetic evaluations (Table 3). A similar trend was observed for the selection of cows as dams. As expected, a higher percentage of the same animals is selected as selection intensity decreases. Therefore, significant differences are expected between the group of animals selected by the RRM and the TM at high selection intensities. For this reason, errors can be expected when choosing sires and dams of future progeny test bulls, as high selection intensities are commonly used in this case.

Significant differences between the RRM and the TM were verified when the ranking of the 20 best bulls (sires of cows with known yield) and of 20 best cows with known yield was analyzed (Table 4). For example, the bull ranked in the sixth position by the RRM was in the nineteenth one when the TM was used. In a small population such as the dairy Gir breed, the use intensity and consequent genetic contribution to the population may differ markedly between animals ranked in these positions. Gains in accuracy of 1 to 3\% were observed for ten of these bulls when the RRM was used. Similarly, gains in accuracy were found for most of the 20 best cows.

Table 3. Total number of animals $(\mathrm{N})$ and number $(\mathrm{NC})$ and percentage $(\% \mathrm{C})$ of common animals selected (\%SEL) for breeding based on the estimated breeding values for 305 -day cumulative milk yield obtained with the random regression model and the traditional model.

\begin{tabular}{|c|c|c|c|c|c|c|}
\hline \multirow[t]{2}{*}{$\%$ SEL } & \multicolumn{3}{|c|}{$\begin{array}{c}\text { Bulls }^{(1)} \\
(\text { rank correlation }=0.96)\end{array}$} & \multicolumn{3}{|c|}{$\begin{array}{c}\text { Cows }^{(2)} \\
(\text { rank correlation }=0.96)\end{array}$} \\
\hline & $\mathrm{N}$ & $\mathrm{NC}$ & $\% \mathrm{C}$ & $\mathrm{N}$ & $\mathrm{NC}$ & $\% \mathrm{C}$ \\
\hline 1 & 9 & 6 & 67 & 106 & 71 & 67 \\
\hline 5 & 44 & 36 & 82 & 529 & 410 & 77 \\
\hline 10 & 88 & 75 & 85 & 1,057 & 851 & 80 \\
\hline 20 & 175 & 157 & 90 & 2,114 & 1,836 & 87 \\
\hline 40 & 351 & 316 & 90 & 4,228 & 3,874 & 92 \\
\hline 60 & 526 & 489 & 93 & 6,343 & 5,943 & 94 \\
\hline 80 & 702 & 670 & 95 & 8,457 & 8,150 & 96 \\
\hline
\end{tabular}

${ }^{(1)}$ Bulls with female offspring with known yield. ${ }^{(2)}$ Cows with known yield. 
The analysis of the whole population showed average increases in accuracy of 2.7,3.0, and 2.6\% for the EBVs of all animals, cows with milk yield record, and bulls (sires of cows with known yield), respectively, when the RRM was used rather than the TM. These increases were lower than those reported in a simulation study in which increases in accuracy ranged from 4 to $8 \%$ for cows and from 2 to $5 \%$ for bulls (Kistemaker, 1997). However, similar increases were obtained by Santos et al. (2014), who analyzed data from Guzerá cattle. The increases in accuracy of the EBVs obtained with the RRM probably would have been higher if data from lactating cows were included, since no adjustment factors are needed to extend lactations. Slightly lower values for accuracy of EBVs were observed for about $6 \%(1,429)$ of the 23,822 animals when using the RRM. Of these, 74 were bulls (sires of cows with known yield), and the mean number of daughters per bull was
1.7 (range: 1 to 9). The gains in accuracy when using the RRM, despite being relatively low, were the main reason several countries adopted this model in routine genetic evaluations, besides the fact that it does not require any additional costs.

The analysis of the genetic trend over time in the studied population (Figure 1) showed the importance of the Brazilian dairy Gir breeding program, Programa Nacional de Melhoramento do Gir Leiteiro (PNMGL), for the genetic improvement of cumulative milk yield in the breed. Until 1985, the genetic gain in Y305 was zero. The mean annual genetic gain was $7.1 \mathrm{~kg}$ between 1985, when the PNMGL program was started with the distribution of semen from the first progeny test group, and 1993. The mean annual genetic gain increased to $56.0 \mathrm{~kg}$ after 1993, when the result of the first progeny test group was published.

Table 4. Comparison of estimated breeding values (EBVs) and rank of the 20 best bulls with female offspring with known yield and cows with known yield obtained with the random regression model (RRM) and the traditional model (TM).

\begin{tabular}{|c|c|c|c|c|c|c|c|c|}
\hline \multirow{2}{*}{$\begin{array}{l}\text { Rank for } \\
\text { the RRM }\end{array}$} & \multicolumn{4}{|c|}{ Bulls } & \multicolumn{4}{|c|}{ Cows } \\
\hline & $\begin{array}{l}\text { EBV for } \\
\text { the RRM }\end{array}$ & $\begin{array}{c}\text { Rank for } \\
\text { the TM }\end{array}$ & $\begin{array}{l}\text { EBV for } \\
\text { the TM }\end{array}$ & $\mathrm{dAC}^{(1)}$ & $\begin{array}{l}\text { EBV for the } \\
\text { RRM }\end{array}$ & $\begin{array}{l}\text { Rank for } \\
\text { the TM }\end{array}$ & $\begin{array}{l}\text { EBV for } \\
\text { the TM }\end{array}$ & $\mathrm{dAC}$ \\
\hline 1 & 1.696 & 1 & 1.964 & 0 & 2.236 & 1 & 2.264 & 3 \\
\hline 2 & 1.456 & 4 & 1.416 & 3 & 2.067 & 7 & 1.941 & 4 \\
\hline 3 & 1.389 & 2 & 1.731 & 0 & 2.004 & 2 & 2.072 & 3 \\
\hline 4 & 1.320 & 3 & 1.500 & 1 & 1.912 & 9 & 1.919 & 2 \\
\hline 5 & 1.313 & 30 & 1.118 & 0 & 1.891 & 18 & 1.834 & 3 \\
\hline 6 & 1.245 & 15 & 1.190 & 2 & 1.849 & 3 & 2.070 & 3 \\
\hline 7 & 1.237 & 6 & 1.363 & 3 & 1.842 & 5 & 2.028 & 1 \\
\hline 8 & 1.232 & 11 & 1.255 & 2 & 1.823 & 10 & 1.915 & 3 \\
\hline 9 & 1.208 & 21 & 1.164 & 3 & 1.784 & 19 & 1.824 & 5 \\
\hline 10 & 1.202 & 13 & 1.203 & 3 & 1.783 & 13 & 1.876 & 3 \\
\hline 11 & 1.180 & 28 & 1.127 & 1 & 1.767 & 11 & 1.912 & 3 \\
\hline 12 & 1.178 & 25 & 1.136 & 2 & 1.732 & 176 & 1.350 & 4 \\
\hline 13 & 1.142 & 8 & 1.343 & 1 & 1.722 & 26 & 1.771 & 1 \\
\hline 14 & 1.137 & 32 & 1.108 & 2 & 1.719 & 6 & 1.976 & 5 \\
\hline 15 & 1.135 & 7 & 1.358 & 0 & 1.716 & 4 & 2.048 & 2 \\
\hline 16 & 1.110 & 16 & 1.181 & 2 & 1.710 & 34 & 1.711 & 3 \\
\hline 17 & 1.097 & 18 & 1.177 & 3 & 1.709 & 8 & 1.922 & 3 \\
\hline 18 & 1.095 & 26 & 1.134 & 0 & 1.701 & 12 & 1.898 & 3 \\
\hline 19 & 1.090 & 23 & 1.140 & 1 & 1.661 & 20 & 1.817 & 3 \\
\hline 20 & 1.071 & 5 & 1.377 & 2 & 1.654 & 89 & 1.515 & 3 \\
\hline
\end{tabular}

${ }^{(1)} \mathrm{dAC}$, percent gain or loss in the accuracy of EBVs when the TM is replaced with the RRM. 
The first (b0) and second (b1) coefficients of the orthogonal Legendre polynomials describe total yield during lactation and persistency, respectively (Jamrozik et al., 2002; Pereira et al., 2013a). The average EBVs for the first regression coefficient (b0) showed a trend similar to that seen for Y305 (Figure 2). This was expected since this coefficient is strongly associated with Y305; the correlation between the EBV for b0 and

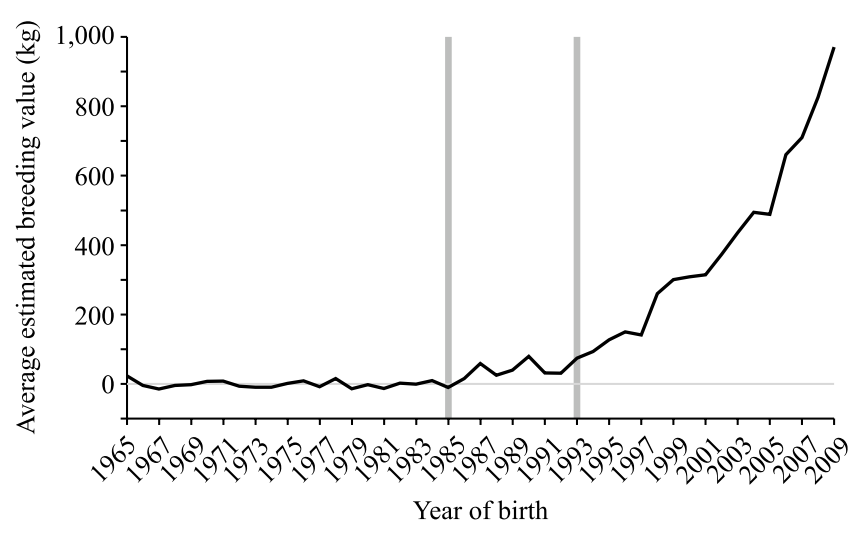

Figure 1. Average estimated breeding values for 305-day cumulative milk yield according to year of birth of the Gir animals. Bar over year 1985 represents the beginning of the Brazilian dairy Gir breeding program, and over 1993, the publication of the first progeny test result.

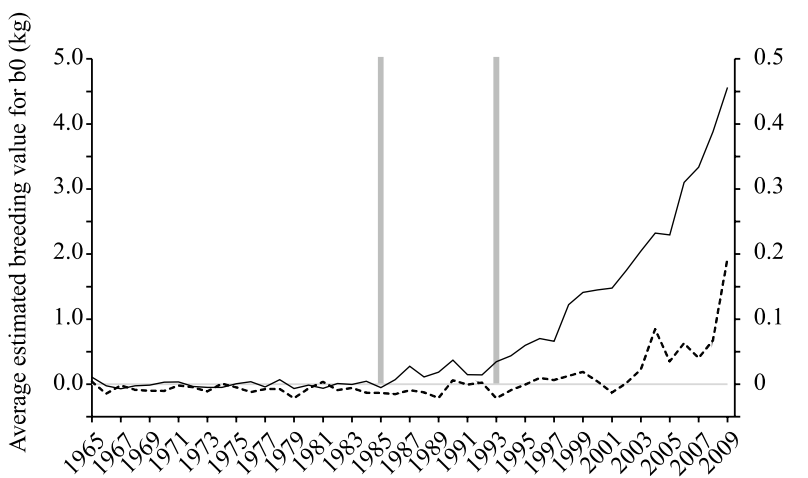

Year of birth

Figure 2. Average estimated breeding values for the first two coefficients of the orthogonal Legendre polynomial (b0 and b1, respectively) according to year of birth of the Gir animals. Bar over year 1985 represents the beginning of the Brazilian dairy Gir breeding program, and over 1993, the publication of the first progeny test result.
EBV305 was equal to 1. However, lower increases in the average EBVs of the animals after 1993 were observed for the second regression coefficient, a finding related to persistency (Jamrozik et al., 2002).

Bulls with lower EBV for b1 sire cows with lower persistency. Bulls A and B presented similar EBV305 of 853 and $884 \mathrm{~kg}$, respectively (Figures 3 and 4).

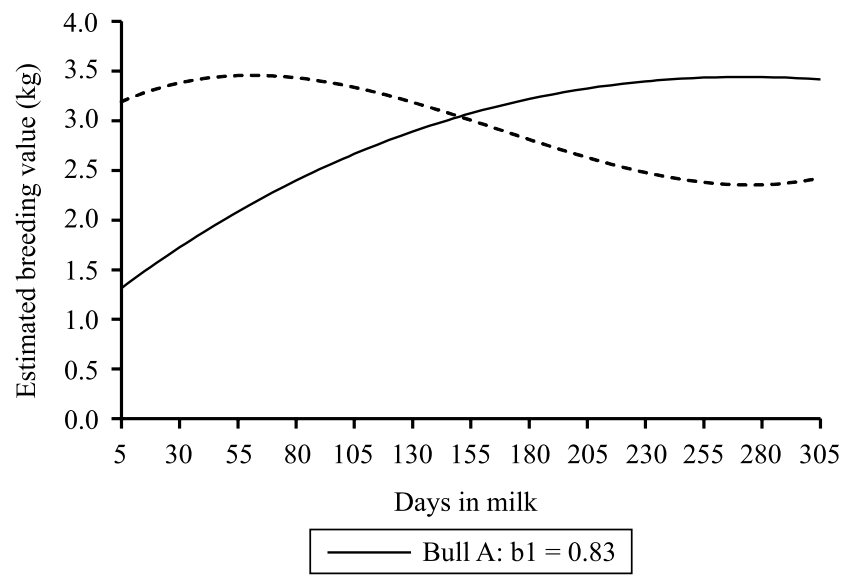

Figure 3. Estimated breeding values according to days in milk obtained for bulls A and B, which have similar breeding values for cumulative milk yield and different breeding values for the second coefficient of the orthogonal Legendre polynomial (b1).

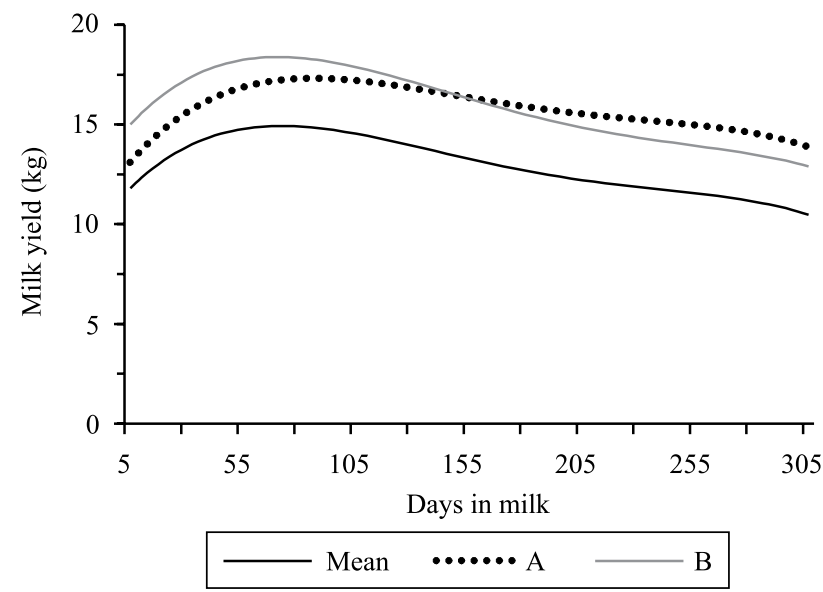

Figure 4. Mean lactation curve of the dairy Gir breed and curves estimated for daughters of the two bulls with similar estimated breeding values for the 305-day cumulative milk yield and positive (A) or negative (B) estimated breeding values for the second coefficient of the orthogonal Legendre polynomial. 
However, EBV for b1 was positive for bull A $(0.83 \mathrm{~kg})$ but negative for bull $\mathrm{B}(-0.56 \mathrm{~kg})$, resulting in different breeding value patterns across lactation (Figure 3). As an example, consider a standard lactation curve compatible with the mean of the studied population (Figure 4). The estimated mean curves of the daughters of bulls A and B are obtained by adding the respective expected progeny differences of each bull to each daily yield, and there is a clear increase in the level of production provided by the use of both bulls. However, daughters of bull A will be more persistent (flatter lactation curves) than those of bull B. By using a RRM, breeders are able carry out genetic evaluation for persistency and can select individuals for this trait too.

The genetic trends for milk yield in the different days in milk indicate, generally, higher genetic gains in milk yield after 50 days of lactation, when compared with early lactation (Figure 5). This result is expected since the estimated heritabilities were higher after 50 days of lactation and selection has been based on EBV305, i.e., the same weights were attributed to the EBVs between days 5 and 305. The highest genetic gains were obtained at about 100 and 305 days of lactation, indicating a long-term change in the time of peak milk yield, which currently occurs at about 60 70 days of lactation.

It is believed that cows with lower milk yields at the beginning of lactation and higher persistency are subject to less physiological stress, minimizing the incidence of reproductive problems and metabolic diseases (Sölkner \& Fuchs, 1987; Muir et al., 2004; Appuhamy et al., 2009). Another important benefit attributed to more persistent cows is their reduced need of concentrate feed during the lactation period to produce a certain amount of milk (Sölkner \& Fuchs, 1987).

In the case of the dairy Gir cattle, whose advantage is their good performance in pasture-based production systems, milk yield persistency is even more important since maximum milk yield is limited by nutritional factors. According to Santos et al. (2007), the maximum yield is approximately $14 \mathrm{~kg}$ milk per day for cows exclusively fed tropical forages and $30 \mathrm{~kg}$ milk per day for cows receiving concentrate supplements on intensively managed tropical pastures. Higher production levels are possible, but require the removal of the animals from the pasture and the use of a feedlot system, at least during a certain period of lactation, which increases production costs. Therefore,

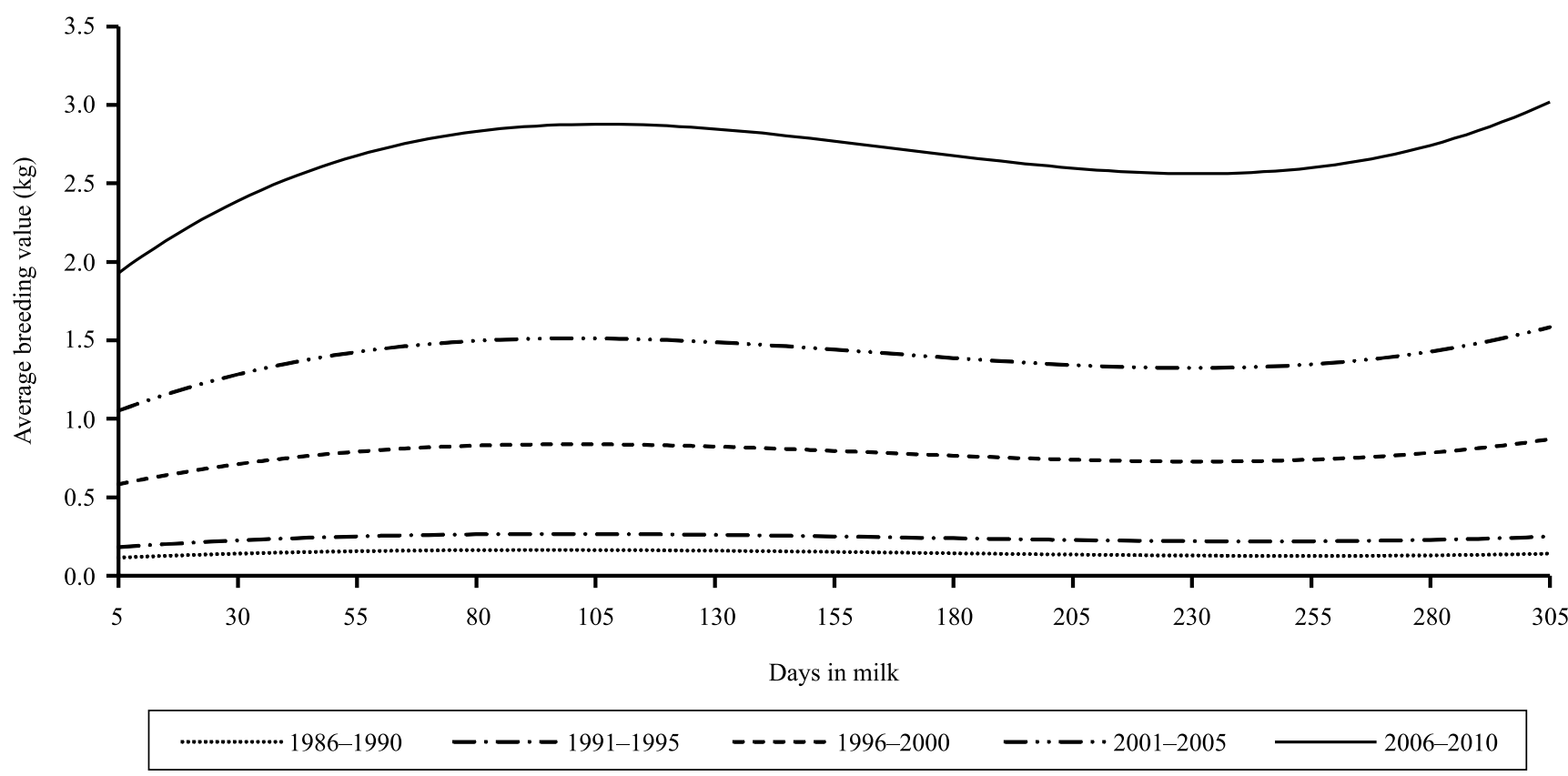

Figure 5. Average estimated breeding values according to days in milk and year of birth of the Gir animals. 
in order to increase cumulative milk yield without the need to remove the animals from the pasture, it is necessary to increase persistency. However, further studies are needed to estimate the economic weights for these traits.

\section{Conclusions}

1. Gains in accuracy and differences in animal ranking are obtained with the use of the random regression model instead of the traditional model for genetic evaluations of dairy Gir cattle.

2. The random regression model presents statistical adequacy and can easily measure persistency, indicating its efficiency for genetic evaluations of productive traits in the Gir breed.

\section{References}

APPUHAMY, J.A.D.R.N.; CASSELL, B.G.; COLE, J.B. Phenotypic and genetic relationships of common health disorders with milk and fat yield persistencies from producer-recorded health data and test day yields. Journal of Dairy Science, v.92, p.1785-1795, 2009. DOI: https://doi.org/10.3168/jds.2008-1591.

ABCZ. Associação Brasileira dos Criadores de Zebu. Estatística Geral 1939 a 2016. 2017. Available at: <http://www.abcz.org.br/ Home/Conteudo/22889-Estatisticas>. Accessed on: Sept. 52017.

BOLIGON, A.A.; BALDI, F.; MERCADANTE, M.E.Z.; LOBO, R.B.; PEREIRA, R.J.; ALBUQUERQUE, L.G. Breeding value accuracy estimates for growth traits using random regression and multi-trait models in Nelore cattle. Genetics and Molecular Research, v.10, p.1227-1236, 2011. DOI: https://oi.org/10.4238/ vol10-2gmr1087.

HERRERA, L.G.G.; EL FARO, L.; ALBUQUERQUE, L.G. de; TONHATI, H.; MACHADO, C.H.C. Estimativas de parâmetros genéticos para a produção de leite e persistência da lactação em vacas Gir, aplicando modelos de regressão aleatória. Revista Brasileira de Zootecnia, v.37, p.1584-1594, 2008. DOI: https://doi.org/10.1590/S1516-35982008000900009.

GONZALEZ-HERRERA, L.G.; EL FARO, L.; BIGNARDI, A.B.; PEREIRA, R.J.; MACHADO, C.H.C.; ALBUQUERQUE, L.G. Random regression analysis of test-day milk yields in the first and second lactations of Brazilian Gyr cows. Genetics and Molecular Research, v.14, p.16497-16507, 2015. DOI: https://doi.org/10.4238/2015.December.9.22.

INTERBULL. National genetic evaluation forms provided by countries. 2017. Available at: <http://www.interbull.org/ib/ geforms $>$. Accessed on: Sept. 52017.

JAMROZIK, J.; SCHAEFFER, L.R.; WEIGEL, K.A. Estimates of genetic parameters for single- and multiple-country test-day models. Journal of Dairy Science, v.85, p.3131-3141, 2002. DOI: https://doi.org/10.3168/jds.S0022-0302(02)74401-9.
KISTEMAKER, G.J. The comparison of random regression test day models and a 305-day model for evaluation of milk yield in dairy cattle. 1997. 181p. Thesis (Degree of Doctor) University of Guelph, Guelph.

MEYER, K. Scope for a random regression model in genetic evaluation of beef cattle for growth. Livestock Production Science, v.86, p.69-83, 2004. DOI: https://doi.org/10.1016/S03016226(03)00142-8.

MEYER, K. WOMBAT - a tool for mixed model analyses in quantitative genetics by restricted maximum likelihood (REML). Journal of Zhejiang University SCIENCE B, v.8, p.815-821, 2007. DOI: https://doi.org/10.1631/jzus.2007.B0815.

MUIR, B.L.; FATEHI, J.; SCHAEFFER, L.R. Genetic relationships between persistency and reproductive performance in first-lactation Canadian Holsteins. Journal of Dairy Science, v.87, p.3029-3037, 2004. DOI: https://doi.org/10.3168/jds.S00220302(04)73435-9.

OLIVEIRA, H.R. de ; SILVA, F.F. e; SILVA, M.V.G.B. da; SIQUEIRA, O.H.G.B. da; MACHADO, M.A.; PANETTO, J.C. do C., GLÓRIA, L.S.; BRITO, L.F. Bayesian Models combining Legendre and B-spline polynomials for genetic analysis of multiple lactations in Gyr cattle. Livestock Science, v.201, p.7884, 2017. DOI: https://doi.org/10.1016/j.livsci.2017.05.007.

PANETTO, J.C. do C.; SILVA, M.V.G.B. da; VERNEQUE, R. da S.; MACHADO, M.A.; FERNANDES, A.R.; MARTINS, M.F.; REIS, D.R. de L.; ARBEX, W.A.; MACIEL, R.S.; VENTURA, H.T.; PEREIRA, M.A. (Ed.). Programa Nacional de Melhoramento do Gir Leiteiro: Sumário Brasileiro de Touros: resultado do teste de progênie: abril 2018. Juiz de Fora: Embrapa Gado de Leite, 2018. 96p. (Embrapa Gado de Leite. Documentos, 216)

PEREIRA, R.J.; LOPES, P.S.; VERNEQUE, R. da S.; SANTANA JÚNIOR, M.L.; LAGROTTA, M.R.; TORRES, R. de A. Funções de covariância para produção de leite no dia do controle em bovinos Gir leiteiro. Pesquisa Agropecuária Brasileira, v.45, p.1303-1311, 2010. DOI: https://doi.org/10.1590/S0100204X2010001100011.

PEREIRA, R.J.; VERNEQUE, R.S.; LOPES, P.S.; SANTANA JR., M.L.; LAGROTTA, M.R.; TORRES, R.A.; VERCESI FILHO, A.E.; MACHADO, M.A. Milk yield persistency in Brazilian Gyr cattle based on a random regression model. Genetics and Molecular Research, v.11, p.1599-1609, 2012. DOI: https://doi. org/10.4238/2012.June.15.9.

PEREIRA, R.J.; AYRES, D.R.; EL FARO, L.; VERCESI FILHO, A.E.; VERNEQUE, R. da S.; ALBUQUERQUE, L.G. de. Genetic parameters for production traits of dairy Gyr $($ Bos indicus $) \times$ Holstein cattle estimated with a random regression model. Livestock Science, v.158, p.24-31, 2013a. DOI: https://doi.org/10.1016/j.livsci.2013.10.003.

PEREIRA, R.J.; BIGNARDI, A.B.; EL FARO, L.; VERNEQUE, R.S.; VERCESI FILHO, A.E.; ALBUQUERQUE, L.G. Random regression models using Legendre polynomials or linear splines for test-day milk yield of dairy Gir (Bos indicus) cattle. Journal of Dairy Science, v.96, p.565-574, 2013b. DOI: https://doi.org/10.3168/jds.2011-5051. 
ROSO, V.M.; SCHENKEL, F.S. AMC - a computer program to assess the degree of connectedness among contemporary groups. In: WORLD CONGRESS ON GENETICS APPLIED TO LIVESTOCK PRODUCTION, 8., 2006, Belo Horizonte. Proceedings. Belo Horizonte: Instituto Prociência, 2006. p.26. (Communication, 27).

SANTANA JR., M.L.; PEREIRA, R.J.; BIGNARDI, A.B.; VERCESI FILHO, A.E.; MENÉNDEZ-BUXADERA, A.; EL FARO, L. Detrimental effect of selection for milk yield on genetic tolerance to heat stress in purebred Zebu cattle: genetic parameters and trends. Journal of Dairy Science, v.98, p.90359043, 2015. DOI: https://doi.org/10.3168/jds.2015-9817.

SANTOS, F.A.P.; MARTINEZ, J.C.; GRECO, L.F.; CARARETO, R.; PENATI, M.A. Suplementação de vacas sob pastejo: considerações técnicas e econômicas visando maior rentabilidade. In: CARVALHO, M.P.; SANTOS, M.V. (Org). O Brasil e a nova era do mercado de leite: compreender para competir. Uberlândia: Impressão Gráfica Rio Pedrense, 2007. p.249-300.

SANTOS, D.J.A.; PEIXOTO, M.G.C.D.; ASPILCUETA BORQUIS, R.R.; PANETTO, J.C.C.; EL FARO, L.; TONHATI, H. Predicting breeding values for milk yield of Guzerá (Bos indicus) cows using random regression models. Livestock Science, v.167, p.41-50, 2014. DOI: https://doi.org/10.1016/j.livsci.2014.05.023.

SCHAEFFER, L.R.; JAMROZIK, J.; KISTEMAKER, G.J.; VAN DOORMAAL, B.J. Experience with a test-day model. Journal of Dairy Science, v.83, p.1135-1144, 2000. DOI: https://doi.org/10.3168/jds.S0022-0302(00)74979-4.

SÖLKNER. J.; FUCHS, W. A comparison of different measures of persistency with special respect to variation of test-day milk yields. Livestock Production Science, v.16, p.305-319, 1987. DOI: https://doi.org/10.1016/0301-6226(87)90001-7. 